\title{
COMPARATIVE STUDY OF FINDINGS OF PREOPERATIVE COMPUTERISED TOMOGRAPHY OF MASTOIDS WITH INTRAOPERATIVE FINDINGS IN CASES WITH CSOM
}

\author{
Ranjan Kumar Nath1, Biraj Kumar Das², Madhurjya KR Thakur³, Mrinmoy Mayur Choudhury4
}

${ }^{1}$ Assistant Professor, Department of ENT, Fakhruddin Ali Ahmed Medical College and Hospital, Barpeta, Assam. 2Professor and HOD, Department of ENT, Fakhruddin Ali Ahmed Medical College and Hospital, Barpeta, Assam. 3 Professor and HOD, Department of Radiodiagnosis, Fakhruddin Ali Ahmed Medical College and Hospital, Barpeta, Assam. ${ }^{4}$ Registrar, Department of ENT, Fakhruddin Ali Ahmed Medical College and Hospital, Barpeta, Assam.

\section{ABSTRACT}

\section{BACKGROUND}

Patients with chronic suppurative otitis media are very common in Barpeta district of Assam. It is also common and frequent OPD visitors in medical colleges and other hospitals across India. HRCT mastoids play an important role in diagnoses of CSOM, selection of surgical procedures and to know the anatomic details of temporal bone in revision cases.

\section{METHOD AND MATERIALS}

The aim of the study is to evaluate the findings of preoperative HRCT mastoids and to determine the accuracy and the usefulness of these imaging methods in patients with CSOM undergoing surgery by comparing with intraoperative findings. The study was carried out at Department of ENT and Department of Radiology of Fakhruddin Ali Ahmed Medical College and hospital from January 2012 to january2015. A total no of 50 patients with atticoantral variety of CSOM are included in the study. Preoperative HRCT mastoid done in all cases were planned for mastoid exploration.

\section{RESULT}

The study shows a sensitivity and specificity of $100 \%$ with regards to soft tissue masses in mastoids and middle ears. The sensitivity and specificity in respect to ossicular erosion, sinus plate erosion, LSCC, facial canal and tegmen plate dehiscence ranges from 70 to $100 \%$.

\section{CONCLUSION}

The study shows HRCT is a good preoperative tool which can determine disease extension in middle ear, attic and mastoid region.

\section{KEYWORDS}

CSOM, Preoperative, HRCT Mastoids, LSCC, Intraoperative Findings.

HOW TO CITE THIS ARTICLE: Nath RK, Das BK, Thakur MKR, et al. Comparative study of findings of preoperative computerised tomography of mastoids with intraoperative findings in cases with CSOM. J. Evolution Med. Dent. Sci. 2016;5(79):5882-5884, DOI: $10.14260 /$ jemds/2016/1327

\section{INTRODUCTION}

Patients with chronic suppurative otitis media are very common and frequent OPD visitors in medical colleges and other hospitals across India. It is also very common in Barpeta district of Assam because of poor socio-economic status, overcrowding, poor hygiene, lack of specialist care and habit of bathing specially in ponds and rivers. Diagnosis of CSOM is mainly made by history, otoscopy and examination under microscope. The X-ray mastoid is done to know mastoid pneumatisation and the level of sinus and dural plates. Other investigations are audiometry to know the degree of hearing loss and pus for culture and sensitivity for microorganisms and choice of antibiotic therapy. Surgical treatment is required for those cases which are not improved with conservative managements, cases of CSOM associated

Financial or Other, Competing Interest: None.

Submission 26-08-2016, Peer Review 17-09-2016,

Acceptance 26-09-2016, Published 01-10-2016.

Corresponding Author:

Dr. Ranjan Kumar Nath,

Assistant Professor,

Department of ENT,

Fakhruddin Ali Ahmed Medical College \& Hospital,

Barpeta, Assam-781301.

E-mail:dr.ranjan25@gmail.com

DOI: $10.14260 /$ jemds $/ 2016 / 1327$ with cholesteatoma and also those cases with extracranial or intracranial complications. Previously mastoid surgery was based on clinical examinations, otoscopy and microscopic examinations. Imaging of the temporal bone by HRCT scan and MRI scan plays an important role in diagnosing cases, selection of surgical procedures and also follow-up. Evidence of location and extension of disease and of asymptomatic complications secondary to bony erosion influence the management and selection of surgical procedures.(1) Computerised tomography provides reliable details of temporal bone anatomy, congenital malformations, levels of sinus and dural plates and pneumatisation of mastoids. HRCT can show subtle details of cholesteatoma and its extension, involvement of hidden areas, e.g. sinus tympani and facial recess.

Information regarding ossicular chain erosion, erosion of LSSC and fallopian canal can also be appreciated by HRCT. However, there are concerns that CT scan cannot differentiate between cholesteatoma and granulation tissue and it lacks guaranteed sensitivity for erosive complications.(1) Such concerns have raised doubts on its value as routine investigation.

The aim of the study is to evaluate the findings of preoperative HRCT mastoids and to determine the accuracy and the usefulness of these imaging methods in patients with 
CSOM undergoing surgery by comparing with intraoperative findings. Intraoperative findings are considered as final findings.

\section{MATERIALS AND METHODS}

This prospective study was carried out at Department of ENT and Department of Radiology of Fakhruddin Ali Ahmed Medical College and Hospital between 2012 and 2015. A total no. of 50 patients with atticoantral variety of CSOM are included in the study. Patients with chronic comorbid condition like granulomatous disease and residual or recurrent disease after previous operation are excluded.

The diagnoses of atticoantral variety of CSOM are made from history, clinical examination, otoscopy and Examination Under Microscope (EUM). Preoperative HRCT mastoid done in all cases planned for mastoid exploration. HRCT scans are done in 16 slice Philips multiplanar machine and consists of less than $1 \mathrm{~mm}$ cut in axial and coronal sections. CT findings are evaluated by a single radiologist. The preoperative CT scan findings are noted and tabulated. Thereafter patients are subjected to either canal wall down or canal wall up mastoidectomy depending on the disease extension. Following areas of interest are noted in preoperative HRCT Scan.

1. Soft tissue mass.

2. Aeration of mastoid.

3. Extension of disease.

4. Sinus plate erosion.

5. Dural plate erosion.

6. Lateral semicircular canal dehiscence.

7. Facial canal dehiscence.

8. Status of incus, malleus and stapes.

9. Extension beyond mastoid.

RESULTS

\begin{tabular}{|c|c|c|c|c|c|c|}
\hline & CT Scan & Per Operative & $\begin{array}{c}\text { False } \\
\text { Positive }\end{array}$ & $\begin{array}{c}\text { False } \\
\text { Negative }\end{array}$ & Sensitivity & Specificity \\
\hline Scutum erosion & 40 & 38 & 2 & 0 & $100 \%$ & $85 \%$ \\
\hline Tegmen erosion & 12 & 5 & 8 & 1 & $83 \%$ & $84 \%$ \\
\hline Sinus plate erosion & 5 & 4 & 1 & 0 & $100 \%$ & $97 \%$ \\
\hline Lateral canal erosion & 3 & 1 & 2 & 0 & $100 \%$ & $96 \%$ \\
\hline Facial Canal Dehiscence & 5 & 2 & 3 & 0 & $100 \%$ & $94 \%$ \\
\hline Malleus erosion & 38 & 34 & 6 & 2 & $100 \%$ & $80 \%$ \\
\hline Incus erosion & 41 & 38 & 5 & 2 & $95 \%$ & $70 \%$ \\
\hline Stapes erosion & 18 & 9 & 12 & 3 & $75 \%$ & $77 \%$ \\
\hline Mesotympanum involvement & 25 & 25 & 0 & 0 & $100 \%$ & $100 \%$ \\
\hline Attic involvement & 40 & 40 & 0 & 0 & $100 \%$ & $100 \%$ \\
\hline Mastoid involvement & 31 & 31 & 0 & 0 & $100 \%$ & $100 \%$ \\
\hline Aditus widening & 31 & 28 & 4 & 1 & $96 \%$ & $84 \%$ \\
\hline \multicolumn{7}{|r|}{} \\
\hline
\end{tabular}

32 out of 50 patients were males and remaining 18 were females. On examination under microscope 31 cases had attic perforation with cholesteatoma flakes, 14 cases with posterosuperior retraction pocket and 3 patients had attic retraction pocket and 2 patients were with posterosuperior retraction with central perforations.

\section{DISCUSSION}

In the literature, it is shown wide variation in the reported sensitivity and specificity of HRCT of the temporal bone. In general, our findings are similar to those reported, Table 2.

\begin{tabular}{|c|c|c|c|}
\hline & & $\begin{array}{l}\text { Our } \\
\text { Study }\end{array}$ & Literature \\
\hline \multirow{2}{*}{$\begin{array}{c}\text { Soft tissue } \\
\text { mass }\end{array}$} & Sensitivity & $100 \%$ & $89 \%-100 \%$ \\
\hline & Specificity & $100 \%$ & $100 \%$ \\
\hline \multirow{2}{*}{$\begin{array}{l}\text { Sinus plate } \\
\text { erosion }\end{array}$} & Sensitivity & $100 \%$ & $67-98 \%$ \\
\hline & Specificity & $97 \%$ & $66.7-93 \%$ \\
\hline \multirow{2}{*}{$\begin{array}{l}\text { Ossicular } \\
\text { erosion }\end{array}$} & Sensitivity & $75-100 \%$ & $56-100 \%$ \\
\hline & Specificity & $70-80 \%$ & $54 \%-89 \%$ \\
\hline \multirow{2}{*}{$\begin{array}{c}\text { LSCC } \\
\text { dehiscence }\end{array}$} & Sensitivity & $100 \%$ & $0-97 \%$ \\
\hline & specificity & $96 \%$ & $83 \%-96 \%$ \\
\hline \multirow{2}{*}{$\begin{array}{l}\text { Tegmen } \\
\text { plate } \\
\text { dehiscence }\end{array}$} & Sensitivity & $83 \%$ & $6-100 \%$ \\
\hline & Specificity & $84 \%$ & $74-96 \%$ \\
\hline \multirow{2}{*}{$\begin{array}{l}\text { Facial canal } \\
\text { dehiscence }\end{array}$} & Sensitivity & $100 \%$ & $0-100 \%$ \\
\hline & Specificity & $94 \%$ & $86-95 \%$ \\
\hline
\end{tabular}

Table 2: Comparison of Sensitivity and Specificity to those Reported in Literature
HRCT mastoid is better than conventional radiograph in preoperative assessment of cholesteatoma. It gives a detailed anatomical picture of temporal bone and possible variations of anatomy in re-do cases. In our study, we found soft tissue density in mesotympanum, attic and mastoid with a sensitivity and specificity of $100 \%$. Our results are similar to study made by Sandeep Sreedhar et al(2) But studies by Sirigiri and Dwaraknath,(3) Mafee et al,(4) O’Reilly et al(5) and Shaffer et al(6) found sensitivity of 90 to $94 \%$ and specificity of 60 to $70 \%$. Though Jackler et al(7) and Garber and $\operatorname{Dort}^{(8)}$ found it to be less sensitive and specific.
However, HRCT is less sensitive in differentiating the type of soft tissue disease whether it is cholesteatoma or granulation tissue or fluid collection in middle ear and mastoid. Previous studies have shown it to be a poor diagnostic tool in this area.[8-11] The author will be agreeing with other authors that active squamous variety of CSOM is a condition, which is mostly diagnosed clinically.[12]

In our study, the decision of operation was made on the basis of clinical findings mainly on pre-operative examination under microscope (EUM). The scan was used as an adjunct to provide additional information for surgical planning and to 
aid informed consent preoperatively. This is supported by Sethi $\mathrm{N}$ et al[12] and Banerjee et al.[13]

In our study, we found that HRCT has high sensitivity and specificity for detecting malleus and incus erosion as compared to stapes erosion. This is in agreement with studies by Sreedhar et al[2] Mafee et al,[4] Shaffer et al,[6] Jackler et al[7] and Garber et al[8] Using HRCT, Mafee et al[4] was able to diagnose state of ossicular erosion in $89 \%$ cases and Jackler et al[7] in $83 \%$ cases. In contrast, $0^{\prime}$ Reilly[5] could detect ossicular erosion in $50 \%$ cases. Sethi $\mathrm{N}$ et al[12] shows a sensitivity of $35 \%$ and specificity of $43 \%$ of HRCT for ossicular erosion. Our study has high sensitivity and specificity for malleus and incus erosion as compared to stapes erosion because of presence of soft tissue density around it make difficult to identify erosion. In this regard, we got the same result as Sreedhar et al.[2] According to Sethi N et $\mathrm{al},[12]$ there is no clear radiological definition of what is a bony defect/dehiscence (i.e. what is minimum size detectable by HRCT). This lack of clarity may contribute to the low sensitivity and variable specificity.

Sirigiri and Dwaraknath,[3] O'Reilly et al,[5] Jackler et al[7] and Garber and Dort ${ }^{[8]}$ were able to diagnose dehiscence in horizontal part of facial canal with $60 \%$ sensitivity and $90 \%$ specificity. In our study we got a sensitivity of $100 \%$ and specificity of $94 \%$, which is comparable to the study made by Sreedhar et al[2] and Jackler et al.[7] The variable results can be explained by the small number of cases of facial canal dehiscence and statement made by Mafee et al ${ }^{[4]}$ and Garg $\mathrm{P}$ et al. [10]

They stated that visualisation of thin bony structures like facial canal may be misleading due to error in computer reconstruction of their images. These structures may be appearing eroded due to the fact that computer averages their density with adjacent soft tissue and air.[4]

Sheehy et al[11] states that lateral semicircular canal fistula are seen in $10 \%$ cases of unsafe CSOM. Their preoperative recognition might reduce the chances of dead ear. O'Donoghue et al[14] and Bates et al[15] had detected 4 out of 5 lateral canal fistula using HRCT. In our study HRCT shows LSSC fistula in 3 cases, but intraoperatively we found fistula in one case. Therefore, we got sensitivity of $100 \%$ and specificity of $96 \%$. Our findings are comparable to the study made by Sreedhar et al[2] and Sirigiri and Dwaraknath et al.[3]

In our study, we got sensitivity and specificity for tegmen plates erosion were $83 \%$ and $84 \%$ and sinus plate was $100 \%$ and $97 \%$ respectively. There is wide variation in sensitivity and specificity of tegmen and sinus plate erosion in literature. The difference of specificity and sensitivity can be again attributed to less numbers of cases in the study and computed tomography averages their density with adjacent soft tissue and air.[4]

\section{CONCLUSION}

This study shows HRCT is a good preoperative tool, which can determine disease extension in middle ear, attic and mastoid region. There is a good correlation between erosion of malleus and body of incus with intraoperative findings, although long process of incus and stapes could not reliably be detected by HRCT. The disease extension into sinus tympani and involvement of facial canal, lateral semicircular canal, tegmen plates and sinus plate are unpredictable by HRCT.
The HRCT gives a relatively rough guide to surgical anatomy of temporal bone rather than a definitive study. However, it would be mutually beneficial for both surgeon and radiologist to interpret the CT results and comparing them with the intraoperative findings. For the surgeon, a good meticulous anticipatory surgical technique with wide exposure is the key for safe surgery rather than a preoperative CT scan. HRCT can be used as an adjunct to preoperative assessment and counselling of the patients regarding surgical outcomes.

\section{REFERENCES}

1. Yildirim-Baylan M, Ozmen CA, Gun R. An evaluation of preoperative computed tomography on patients with chronic otitis media. Indian Journal Otolaryngol Head Neck Surgery 2012;64(1):67-70.

2. Sreedhar S, Kailash P, Agarwal AC, et al. Role of high resolution computed tomography scan in the evaluation of cholesteatoma: a correlation of high resolution computed tomography with intra-operative findings. Indian J Otology 2015;21(2):103-6.

3. Sirigiri RR, Dwaraknath K. Correlative study of HRCT in attico- antral disease. Inaian J Otolaryngol Head Neck Surg 2011;63(2):155-8

4. Mafee MF, Levin BC, Applebaum EL, et al. Cholesteatoma of middle ear and mastoids, a comparison of CT scan and operative findings. Otolaryngol Clin North Am 1988;21(2):265-93.

5. O'Reilly BJ, Chevretton EB, Wylie I. The value of CT scanning in chronic suppurative otitis media. J Laryngol Otol 1991;105(12):990-4.

6. Shaffer KA, Haughton VM, Wilson CR. High resolution computed tomography of the temporal bone. Radiology 1980;134(2):409-14.

7. Jackler RK, Dillon WP, Schindler RA. Computed tomography in suppurative ear disease: a correlation of surgical and radiological findings. Laryngoscope 1984;94(6):746-52.

8. Garber LZ, Dort JC. Cholesteatoma: diagnosis and staging by CT scan. J Otolaryngol 1994;23(2):121-4.

9. Tatlipinar A, Tuncel A, Ogredik EA. The role of computed tomography scan in chronic otitis media. Eur Arch Otolaryngol 2012;269(1):33-8.

10. Garg P, Kulshreshtha P, Motwani G. Computed tomography in chronic suppurative otitis media: value in surgical planning. Indian J Otolaryn Head Neck Surg 2012;64(3):225-9.

11. Sheehy JL, Brackmann DE, Graham MD. Complications of cholesteatoma. A report 0n 1024 cases. In: McCabe BF, Sade J, Abranson M, eds. First international conference on cholesteatoma. Birmingham, Alabama: Aesculapius press 1977:420-9.

12. Sethi N, Raffertly A, Kayarkar R. How reliable temporal bone CT in mastoid surgery. J Otol Rhinol 2015;4(3):1-3.

13. Banerjee A, Flood LM, Yates P. Computed tomography in suppurative ear disease: does it influence managements? J Laryngol Otol 2003;117(6):454-8.

14. O'Donoghue GM. Imaging of temporal bone. Clinical Otolaryngol 1987;12(3):157-60.

15. Bates GJ, O’Donoghue GM, Anslow P. Can CT detect labyrinthine fistula pre-operatively? Acta Otolaryngol 1988;106(1-2):40-5. 